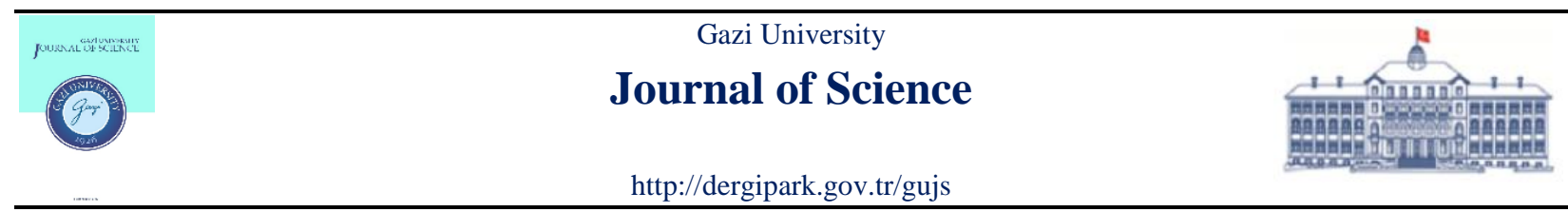

\title{
Integrating Renewable Energy Systems into Urban Furniture for Recreational Spaces: A Design Proposal for Konya Adalet Park
}

\author{
Aysegul TERECI ${ }^{1, *}$ (D) Merve ATMACA ${ }^{2}$ (D) \\ ${ }^{1}$ KTO Karatay University, Faculty of Fine Arts and Design, Department of Architecture, 42020, Konya, Turkey \\ ${ }^{2}$ KTO Karatay University, Faculty of Fine Arts and Design, Department of Interior Architecture, 42020, Konya, Turkey
}

\section{Highlights}

- The use and dissemination of renewable energy technologies in public spaces.

- Design principles of recreational urban furniture.

- Renewable energy integration to recreational urban furniture.

- Sustainable Park Furniture Design Examples.

- $50 \mathrm{MWh} / \mathrm{an}$ electricity production capacity with possible installations for the case study area.

\begin{tabular}{l} 
Article Info \\
\hline \\
Received: 26/02/2019 \\
Accepted: 26/07/2019 \\
Keywords \\
\hline Energy \\
Integrated design \\
Recreational areas \\
Renewables
\end{tabular}

\begin{abstract}
Recreational areas are designed to promote physical activities as well as provide opportunities for relaxation. Recreational open spaces improve the long-term environmental and social sustainability of cities. These areas offer natural beauty in and around cities while sustaining the environmental equilibrium of city life. They also serve as a socialization hub for people to make contact with each other. They can also be promoting areas for sustainability. Introducing the use of technology in public areas will promote its use in daily life also. One area of technological advances that needs to be promoted for establishing sustainable communities is the integration of renewable energy resources for our daily needs. This study focuses on difficulties and strategies for the integration of renewable energy in recreational areas and evaluates a recreational open space; i.e. Adalet Park in Konya in terms of possible applications of renewable energy sources. Since solar energy potential is high in Konya PV integration is the best option for the area. On the other hand, wind power is not sufficient for producing energy with wind turbines, hence, wind belts and small scale wind mills can be integrated into the park furniture. To this end, the design of various urban furniture with integrated renewable energy systems was prepared for the Karatay Adalet Park in Konya; and the amount of energy that can thus be produced was determined. According to calculations using wind and solar data and a software, it is possible to produce $50 \mathrm{MWh} / \mathrm{a}$ of electrical energy with these installations.
\end{abstract}

\section{INTRODUCTION}

Public spaces are places where people can integrate into society and also ingenerate the common culture and identity. Urban public spaces mainly establish the basis for people's communication and activities. Urban open spaces are defined as "third spaces" where individuals get together regularly out of their home (first space) and business life (second space) [1]. Recreational open spaces are defined as the outdoor openair spaces which are used principally for recreational activities or relaxation. National or city parks, special purpose parks, playgrounds for children, sports fields, natural and semi-natural areas such as bodies of water and other open and green areas within the city can be listed as recreational open spaces [2].

The word "recreation" first appeared in the 14th century in France and is defined as "a process of creating anew". The origin of the word came from Latin "recreatio" which means "restoration of health" [3]. More commonly, it is used for the utilization of leisure time that is freely chosen after work or social work. Recreational time has always been a part of human life after the transition into settled life. The 
industrial revolution brought about a significant increase in production, therefore, capital accumulation, which enabled increased wealth, gave people more free time for recreational activities [4].

Recreational open spaces are essential for city life in order to minimize the damages caused by industrialization and urbanization. Recreational activities require a natural and clean environment; therefore, people either have to go far away from the polluted city centres or create natural recreational areas such as parks and playgrounds within the city limits. Recreational open spaces are significant for improving public health and the urban environment. Besides, recreation has begun to gain greater importance since it supports cultural exchanges and ensures social peace in the cities [5]. These areas improve the quality of life in cities by providing an environment that is conducive to living successfully and happily in the most favourable ambient conditions [6]. The term indicates not only the basic needs of individuals but also implies socio-cultural and environmental factors affecting the level of social welfare of individuals. Within this scope, recreational spaces are considered essential to sustain and improve social relationships, as well as mental and physical health of the city dwellers. The quality of life of these people is also closely linked to 'liveability' and 'sustainability" in the built environment. Since recreational open spaces provide a better environment and encourage interaction between people, they ensure that urban areas more sustainable and liveable for now and the future. To this end, the material and equipment used in recreational areas can also be designed to support long-term environmental and social sustainability. For example, such areas can be used to educate the public on environmental sustainability issues like the need to reduce energy consumption in order to reduce environmental pollution or to increase the use of clean energy sources to improve environmental conditions. For this reason, recreational areas are one of the most favourable places to introduce and promote renewable energy sources and technologies.

The use of renewable energy is of great importance, in terms of water quality, air quality and the preservation of natural life. Yet, only $20 \%$ of the world's energy needs are obtained from renewable sources [7]. Increased use of renewable energy has the potential to reduce the dependency on fossil fuels. Not only fossil fuel reserves are being depleted but also the intensive production of energy from fossil fuel releases carbon into the atmosphere which causes climate change. Renewable energy has a key position in meeting the energy needs of countries with domestic resources, reducing external dependency and minimizing the damage to the environment. It is known that renewable energies are inexhaustible, that they can renew themselves continuously and they are compatible with the environment, and these sources of energy will increase with the ever-decreasing initial cost. Hence, government incentives should not only encourage the public to use renewable energy sources but also provide more visibility to such technologies by using them in public places such as parks and playgrounds The integration of renewable energy systems in recreational areas can be done by designing them as a part of the elements that are used in these areas. Hence, instead of allocating special spaces for renewable energy sources, these sources can become more inspiring with specially designed urban furniture that can attract the public's attention.

Within the scope of this study, the design process of the urban furniture that will enable the integration of renewable energy sources into recreational open spaces is evaluated. Such an approach will be practised in the case study area. This research is outlined in three parts. Firstly, the design principles of urban furniture are taken into account and then renewable energy integration to urban furniture in recreational areas is discussed. Finally, one of the case study areas is evaluated according to these strategies and the energy production possibilities which can be brought through design decisions are explained.

\subsection{Design Principles of Urban Furniture in Recreational Areas}

Urban recreation areas address a large number of users depending on the neighbourhood population. The elements used in the urban recreational areas should be designed in accordance with the socio-cultural characteristics of the city and the functional needs of users. Thus furniture and all elements used in recreational areas such as lightings, seating units, floor coverings, garbage cans, barriers, information/ sign boards, sculptures, pools, fountains, and stalls should be designed in compliance with the location where they would be used. A different design process should be applied to each separate unit. It is natural that many different factors are involved in the design of urban furniture. These factors include social issues, psychological issues, semantic issues and aesthetic values [8]. 
When the furniture designs are proper and appropriate, they enhance the comfort and quality of city life. There are many design criteria that should be taken into consideration when designing a certain element. Criteria can make a difference in the design of the city furniture and affect the taste level of the users which can be determined as harmony of colour, measure/ rate balance, functional suitability, material harmony, well-being/ cleanliness, being modern, being new, being historical, referring to history, being different, being impressive, being interesting, well-located, being harmonious with the environment, opposing the environment, being semantic and monumental, being symbolic, creating visual richness. City furniture should own certain design principles that ensure the interaction between citizens, functionality and material use [9].

Human beings perceive, comprehend and also evaluate the space and things around them with their own senses and feelings. This is a spontaneous event. Perceiving interprets the information so that we can act in a correct and appropriate way. It is usually much easier for us to perceive something that we already know. Therefore identifiability of urban furniture is important, thus its definition should be easily understood by the user. If the designs do not take into account the user-friendliness concept or do not include several forms that ensure understanding, people will not easily notice or recognize urban furniture. Consequently, the perception should be tackled and evaluated as a diversifying concept that enhances the imagination and the level of appreciation of the users [10]. Each element of the urban infrastructure has a different meaning and significance for the interests of the users and the city itself. Design items are important for cities because they are the most significant means that contribute to building and developing an urban identity and arrange the environment according to their needs. The biggest contribution to shaping the identity of the city is the language union they form together. For this reason, approaches should be taken in order to ensure that urban elements establish accurate relationships with each other and with the urban spaces [11]. When space is arranged, also designed and customized equipment should create a system for the whole city.

The function contains purpose, necessity, and conformity [12]. The primary function of city furniture is to assist the lives of citizens in urban space and provide them with a comfortable space [13]. The work expected from the space design is that its furniture prevents complexity and redundancy. Thus, the user will receive the best service in a harmonious, original and comfortable place.

Other important design elements are the aesthetic values of the items and the concept of being desirable. A certain aesthetic dimension is required in these spaces. In fact, the pleasure and excitement in a space from an aesthetic point of view increases the liveability of the space. Urban furniture is important not only for its functional purposes but also for visual aspects as urban objects complementing and defining urban spaces. Urban furniture, used especially for visual purposes, have a positive impact on places where they are located, whereas urban furniture which is only functional and not carrying any aesthetic concerns affects the environment negatively [9].

A whole structure can be defined as a form. Form determines the function, dimensions, and materials. The form of an object derives from the function attached to that object and the service required from it. Being usable is the first condition and the purpose of the object should be presented in a proper way [12]. In product design, the material used is one of the most important criteria to consider, because it affects the design in a significant way. The material plays a major role in producing the desired form and bringing the desired characteristics. Material diversity can create different forms, increase the visual quality of the products and enrich the design $[10,14]$. Natural and artificial materials used in the design of urban furniture have a different effect on human psychology. As an example, natural materials like wood evoke the feeling of peace and rest, while earth-based materials revive creativity and imagination and concrete as an artificial material awakens a sense of warning and security [15].

Colour is also an effective design element. All colours have different psychological and visual effects on humans. The colour schemes created have a direct impact on the use of spaces for landscape design [16]. The concepts of urban furniture, texture, and form are closely related to each other. In design, the texture is significant for both technical and aesthetic reasons. It creates interesting surfaces with visual effect and hides minor imperfections [17]. In addition to the shapes of the designs, textures change the features of the 
surface. The light ensures the perception of objects, for this reason, different textural features such as smooth, rough or even polished within different lighting conditions add altered values to the design [14].

To sum up, we can say that in the design of furniture for recreational areas and in all furniture design, the physiological and psychological needs of people should be respected and met. Appropriate and costeffective technologies and materials should be utilized in the construction and production of these designs [18]. In designing objects, the relationship with the place arises from people's psychological and physiological needs.

\subsection{Renewable Energy Integration to Urban Furniture in Recreational Areas}

Renewable energy technologies are used for electricity generation, hot water production and climatization of the spaces. According to the type of recreation area, all of these technologies can be integrated, as shown in Table 1.

Table 1. Renewable energy technologies and integration possibility for recreation areas

\begin{tabular}{|c|c|c|c|c|}
\hline $\begin{array}{l}\text { Renewable } \\
\text { energy }\end{array}$ & $\begin{array}{l}\text { Renewable energy } \\
\text { technology }\end{array}$ & Harvesting & Storage & Recreation area integration \\
\hline Solar & $\begin{array}{l}\text { PV } \\
\text { Solar -thermal }\end{array}$ & $\begin{array}{l}\text { PV panels; } \\
\text { Solar collectors }\end{array}$ & $\begin{array}{l}\text { Solar battery, } \\
\text { Water } \\
\text { storage tank }\end{array}$ & $\begin{array}{l}\text { Lighting, signposts, } \\
\text { information kiosks, pergolas, } \\
\text { Electrical vehicle charging } \\
\text { stations, Solar-powered } \\
\text { Trash Compacting Facilities, } \\
\text { Energy for furniture and } \\
\text { buildings on the area }\end{array}$ \\
\hline Wind & Onshore & $\begin{array}{l}\text { Wind Turbines } \\
\text { Wind Mills or } \\
\text { Pumps } \\
\text { Wind belt }\end{array}$ & $\begin{array}{l}\text { Wind farm } \\
\text { battery } \\
\text { storage, grid } \\
\text { energy } \\
\text { storage }\end{array}$ & $\begin{array}{l}\text { Lighting, Electrical vehicle } \\
\text { charging stations, wind tree, } \\
\text { Energy for furniture and } \\
\text { buildings on the area }\end{array}$ \\
\hline Piezoelectric & Piezoelectric cells & Charging pads & Batteries & Walking area and lighting \\
\hline $\begin{array}{l}\text { Hydro } \\
\text { energy }\end{array}$ & $\begin{array}{l}\text { Runoff river hydro } \\
\text { Storage hydro } \\
\text { Pump storage } \\
\text { hydro energy }\end{array}$ & $\begin{array}{l}\text { Hydro Dams, } \\
\text { Turbines }\end{array}$ & $\begin{array}{l}\text { Pumped } \\
\text { hydro energy } \\
\text { storage }\end{array}$ & $\begin{array}{l}\text { Energy for equipment and } \\
\text { buildings in the area }\end{array}$ \\
\hline Bioenergy & $\begin{array}{l}\text { Biomass } \\
\text { Biofuel }\end{array}$ & $\begin{array}{l}\text { Stirling engines } \\
\text { Org. Rankine } \\
\text { module, } \\
\text { Gasification } \\
\text { plants, } \\
\text { Backpressure } \\
\text { steam turbines, } \\
\text { Biogas plants }\end{array}$ & $\begin{array}{l}\text { Heat storage } \\
\text { systems, } \\
\text { geological } \\
\text { storage, } \\
\text { batteries }\end{array}$ & $\begin{array}{l}\text { Energy for equipment and } \\
\text { buildings in the area }\end{array}$ \\
\hline Geothermal & $\begin{array}{l}\text { Direct use } \\
\text { Geothermal Heat } \\
\text { pump } \\
\text { Geothermal } \\
\text { Electricity } \\
\text { production }\end{array}$ & $\begin{array}{l}\text { Ground Source } \\
\text { Heat Pumps, } \\
\text { Flash Steam } \\
\text { Power Plant, } \\
\text { Heat exchanger }\end{array}$ & $\begin{array}{l}\text { Water } \\
\text { storagetank, } \\
\text { Underground } \\
\text { Thermal } \\
\text { Energy } \\
\text { Storage - }\end{array}$ & $\begin{array}{l}\text { Energy for equipment and } \\
\text { buildings in the area }\end{array}$ \\
\hline
\end{tabular}

Especially, sports fields and commercial activity places in the recreation areas can be designed with renewable energy technologies. The main elements of the recreation areas are the green areas. By simply using renewable energy technologies, regular maintenance of the area and the energy needs of users can be met. Especially, lighting in these areas can be provided by renewable technologies such as sun, wind, geothermal or biomass energy. 
All renewable energy technologies consist of four fundamental components, which are; harvesting, storage, distribution and control of the system. Harvesting is an essential part of the system and it requires special care and attention in the design. It is important to integrate the site resource characterization and the mechanical part of the system in full compliance with safety, security, durability and resiliency rules. The site analysis should be conducted before the design phase; since it evaluates the possibilities and power of energy sources.

For example, solar energy potential on site is related to the available solar radiation on the earth's surface and can be reduced by shade and shadow due to trees and surrounding buildings. Hence, the size of the photovoltaic (PV) collector should be calculated and decided according to the availability of solar light. They should be placed in a way that they are not affected by surrounding obstructions. PV panels can be integrated into the furniture in different ways according to their types. Film-shaped panels can be easily added to the sun-affected surfaces of furniture, although they have different curvatures. Other panels can be used as top cover elements in furniture. Another important component is inverters and their installation in the system. The PV collector and the inverter should be carefully integrated in the urban furniture. Solar energy systems are expensive, so it is necessary that this equipment, which is used outdoors, should not be portable or easily removable. Hence, special safety and installation precautions must be taken during the design phase.

Wind power has been used for turning turbines of various sizes in the urban environment. Urban recreational areas can have wind potential if there are not many obstacles around. The possibility of using wind energy should be defined based on a wind analysis of the area; while micro wind belts can be added to the area as a separator for some places. The wind belts can be integrated into any surface that can receive the wind in furniture, but it is suitable to place them on the upper elevations to prevent damage from human movements. Wind turbines transfer the kinetic energy of wind into electrical energy, thus their electricity capacity is directly related to the wind speed and frequency. The design of the wind harvester requires special attention due to public safety reasons. Wind turbines can cause accidents involving even death or personal injury, so it should be fixed according to extreme wind conditions. Noise and the vibrations of the turbines, visual effect and shadow effect of this dominant component at the area should all be taken into account in the selection of the place for integration [19]. Therefore, the use of micro-scale wind turbines in the form of renewable energy trees in parks will provide a better solution.

Piezoelectric pads can be added to the recreational area as vehicle roads or walking pads. The piezoelectric material is used to absorb the kinetic energy and convert it into electrical energy. The produced energy can be used for lightening the piezoelectric roads [20]. The system can be designed according to the weather conditions of the place and details should be carefully analysed by the producer. Hydro energy and geothermal energy can be used in the recreational area according to the water potential of the site. Water reservoirs can be used for irrigation and hydro-electric power. But on the other hand, such practices should respect the aquatic ecosystem in the recreational areas. A bioenergy power plant is not easily applicable to the recreational area. Urban recreational areas are favourable places to obtain the organic materials used in this plant, however, the plant is big and it does not fit well into recreational area. However, it can be located on the outskirt of the recreational area.

\section{MATERIAL AND METHOD}

First of all, a thorough literature review was conducted in order to study the design process of urban furniture with renewable energy integration, and its placement in the recreational area as shown in Figure 1. 


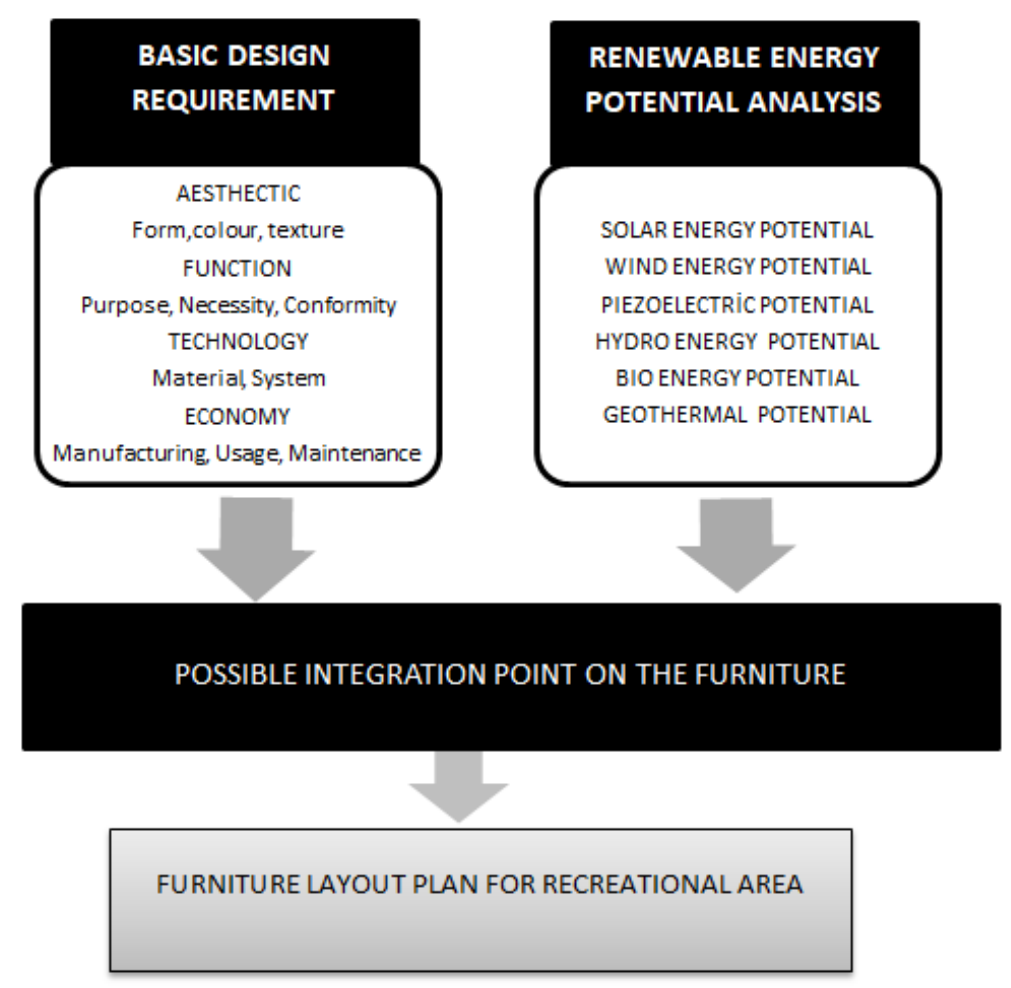

Figure 1. Methodology for design steps for renewable energy integration into recreational areas

The Adalet Park in Konya was selected for a conceptual application of this study. The requirements of the basic design decisions and the potentials of renewable energy technologies to be integrated were examined. The potentials of renewable energy sources in the areas and their integration in the urban furniture were assessed. In the conceptual design phase, certain computer programs and calculations were used in order to measure the sunlight and wind potential. The solar energy potential was calculated by the PVsyst program, which is a preliminary design tool. Piezoelectric and wind belts were calculated according to measurements based on the previous research work [21, 22].

The basic design requirements of the urban furniture were evaluated according to renewable energy potentials. After the conceptual design work had been completed, a layout plan was prepared for the furniture in the park in accordance with the present conditions. In particular, the maximum utilization of renewable energy was taken into consideration.

\section{RESULTS OF THE STUDY}

\subsection{Design Proposal for the Karatay Adalet Park in Konya, Turkey}

The Karatay Adalet Park is selected to test the proposed conceptual design since it is one of the largest parks in the city centre of Konya. The park which was built in 2007 is surrounded by residential, commercial and public buildings, so it has the potential to be a good pilot project in terms of encouraging renewable energy resources. Adalet Park is located in the central Karatay district of Konya and covers an area of $102,000 \mathrm{~m}^{2}$. The park contains a $4,600 \mathrm{~m}^{2}$ pond, walking paths and many sports fields, as shown in Figure 2. 


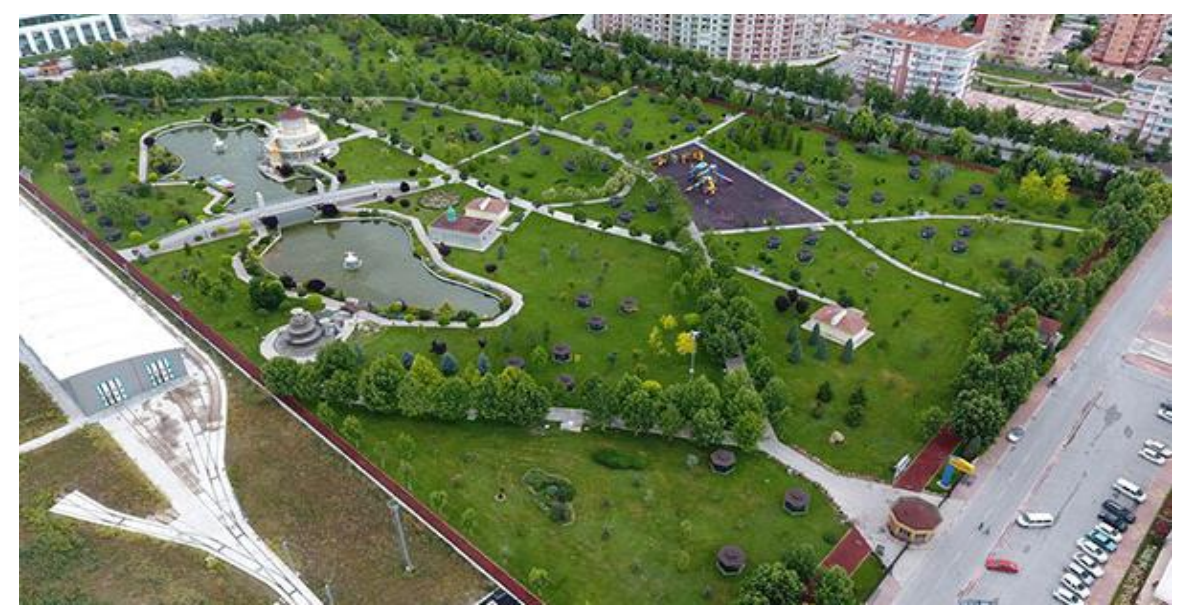

Figure 2. Photograph of Karatay Adalet Park

The park also has 21,000 plants from 192 species, as well as miniatures of some important architectural structures of Turkey. Especially, with 150 large pavilions, the park is an important recreation area for the region. There is a university, a courthouse, business centres, and residential areas in the neighbourhood. In winter, it is a place where employees and students of the surrounding institutions spend their lunch breaks and free time while in the summer months it becomes a picnic area for people living in the entire city. A restaurant is located on the edge of the pond which also offers dining opportunity in the area. Throughout the day and night, sports activities are going on in the park. There are walking trails around the park while the tartan track is 1100 meters long and 3 meters wide, so it offers shaded areas under the trees for those who want to run and walk. The park is used as an area where the whole city can spend its leisure time, given the large car parking lot around it and its close proximity to public transport lines in the area.

In the Park, a uniform style or a common language does not exist in the design of the urban furniture; as can be observed in Figure 3. Cast iron benches and retro style street lamps are used in the circulation areas for seating. In the green areas, wooden pavilions with monitor roof structure create the picnic areas. There are an open basketball court and some exercise and sports equipment installed for the visitors. The lighting in the area is achieved by various floodlight projectors in completely in different styles.

The public bicycle rental service located in the main entrance area gives people the opportunity to rent bicycles for cycling in the park. The rental system is working with PV panel which is supported on top of a metal stand. There is an information board between the PV panel stands. There is no design uniformity between the boards used in the area; some of them are wooden, some are made of metal and also their sizes are different from each other. The buildings in the area use grid electricity for air-conditioning, whereas, the renewable energy that can be produced according to the design proposal, can be used in these buildings.

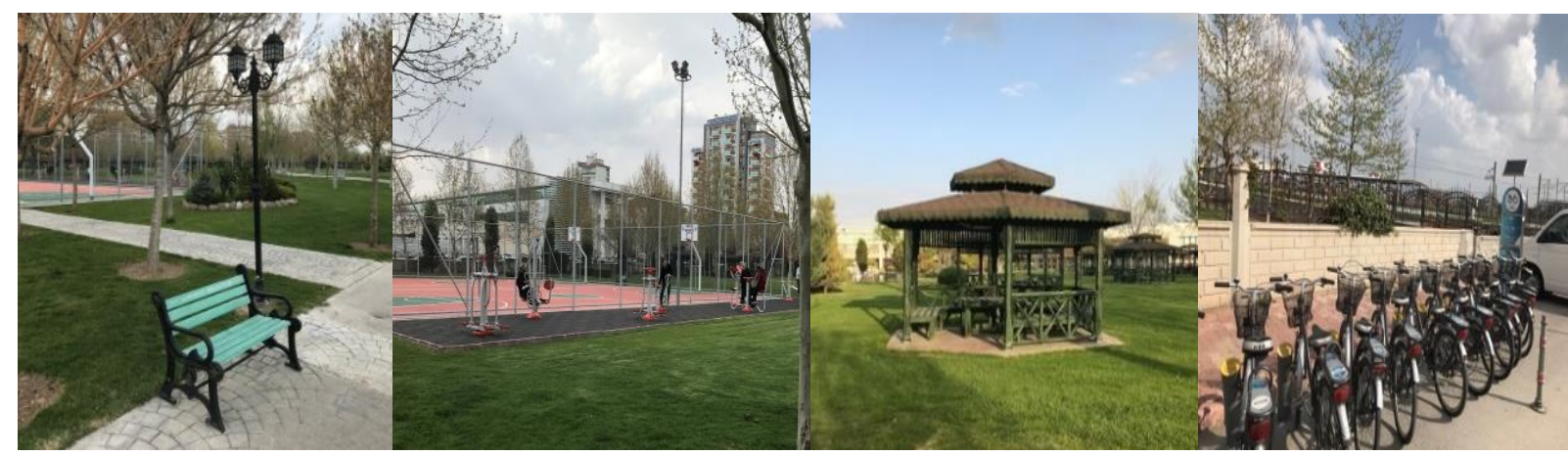

Figure 3. Urban Furniture currently in use in Karatay Adalet Park 


\subsection{Sustainable Park Furniture Designs}

At the first stage of the design, the solar energy potential was analysed with the help of the PVsyst program. Monthly average irradiance levels for Konya city are shown in Figure 4. The analysis showed that there was a high solar energy capacity on the site. The use of this energy in producing hot water for the recreational area as well as for electricity production is possible. According to the computer analysis, the optimum location of the PV panels for both summer and winter conditions was determined to be facing the south direction with a 30-degree tilt angle.

On the other hand, monocrystalline panels were seen to be more efficient than the Polycrystalline ones and thin films, since they have a higher heat tolerance when compared to monocrystalline panels. For this reason, polycrystalline panels were selected and integrated to the Park design and the related calculations were done. The grid-connected system was chosen because the produced electricity could be sent to the grid when it was not used on site and the energy could be supplied from the grid when it was necessary. According to our calculations, $17.3 \mathrm{MWh} /$ year can be produced by using $66 \mathrm{~m}^{2}$ panel area. It was not possible to use all panels on the south direction so the azimuth angle was changed as -30 degree and +30 degree to the south. This calculation showed that for both directions, the $15.2 \mathrm{MWh} / \mathrm{year}$ energy could be produced by $60 \mathrm{~m}^{2}$ panel area.

Konya has $6.8 \mathrm{~m} / \mathrm{s}$ wind speed on $50 \mathrm{~m}$ height. High places are considered as favourable areas for wind turbines and Konya was found to have approximately $1860.08 \mathrm{MW}$ energy potential [23]. Installing a big wind turbine in the park, would not be appropriate, so wind belts were proposed for the system design. As they produce small amounts of electrical power under very low wind speeds, the produced electricity could be used to power the LED lights around the park.

Piezoelectric pads can be installed on the tartan walking pads. As mentioned before, the track is 1100 meters long and 3 meters wide so a section of the track 110 meters long and 1.5-meter wide can easily be separated and arranged for the piezoelectric installation. Since the track is not fully occupied all the time, the peak demand for total energy generation of $525 \mathrm{~W}$ (assuming that all paving is occupied by people jumping at $50 \mathrm{~Hz}$ ) would never be achieved from this area. On the other hand, hydro-electric, geothermal or biomass energy systems cannot be installed in the park for the following reasons: the artificial pond in the park is only $1 \mathrm{~m}$ deep and water does not flow in it; hence, it cannot be used to produce hydro-electric energy. Geothermal sources do not exist close to the area; while there is no suitable area for installing a biomass plant for district heating or cooling. These systems should have been organized before the park came into use, as their installation at this stage would require a major renovation action.

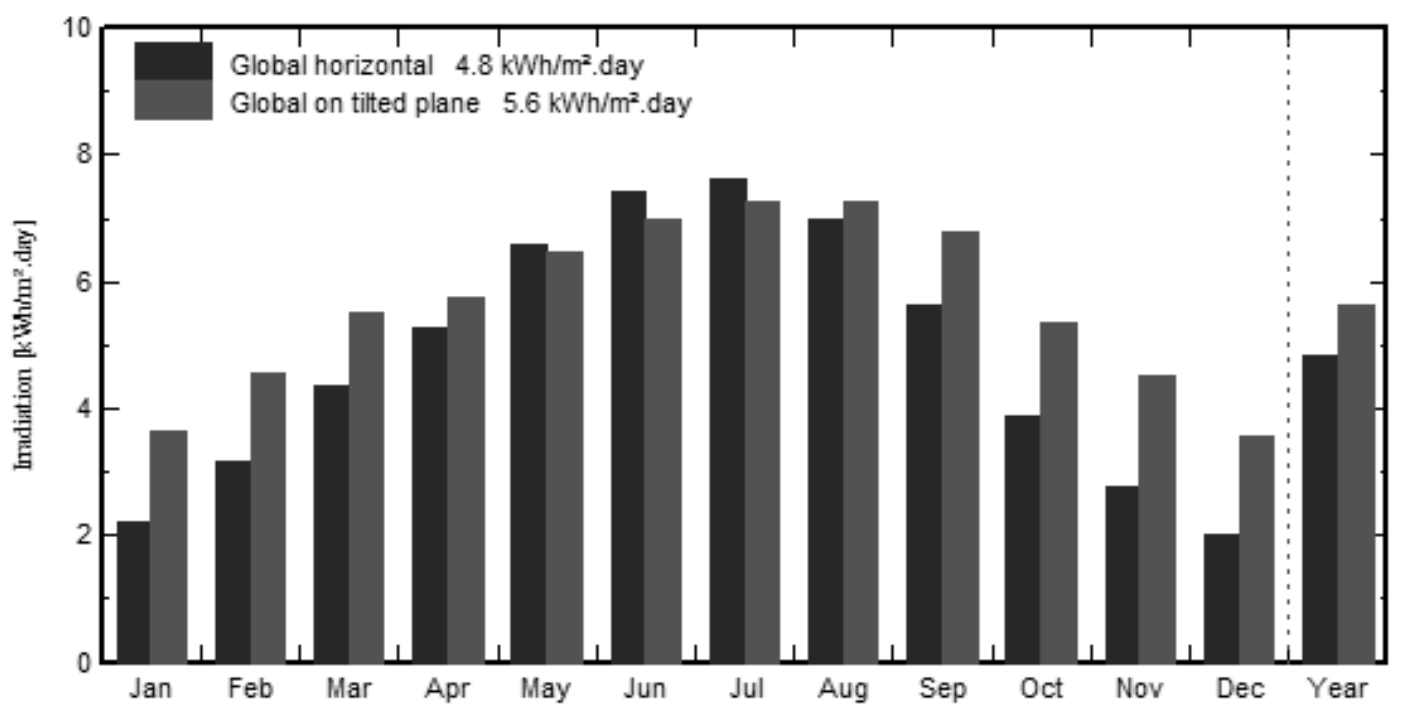

Figure 4. Average Monthly Irradiance in Konya (horizontal and tilt angle $30^{\circ}$ ) 


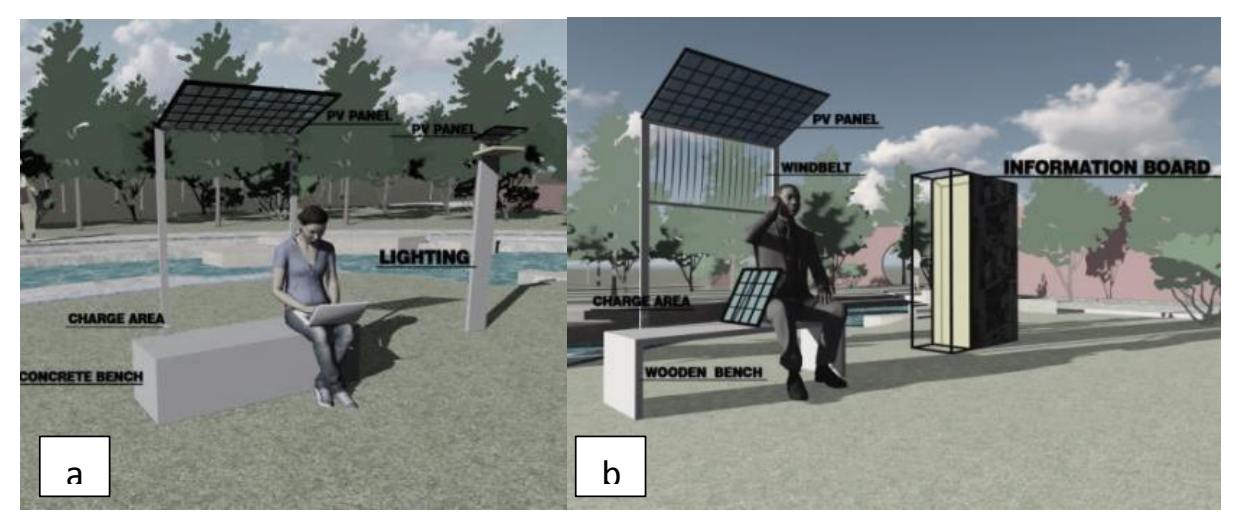

Figure 5. a) Designed concrete bench for the case study area b) Designed wooden bench and information board

Different urban furniture pieces that integrated renewable energy were designed for the park: benches, charging stations, information boards and renewable energy trees, which are described in the following paragraphs. Based on the site analysis, the design concept for the urban furniture incorporates new technologies is practical and modern. The natural colours and textures of concrete, wood and metal were preserved; while the users/visitors', daily needs were taken into account. For instance, they need a charging place for their electronic devices such as cell phones, tablets and laptops; and information boards displaying weather conditions or news about the local area.

PV panels were integrated into urban furniture as much as possible, as shown in Figure 5. These panels are oriented to maximize the amount of energy production and are placed at a $30^{\circ}$ tilt angle. They are fixed to the furniture with a strong metal frame. These frames also serve to hide the cables of the panels. Some components of the energy generating system, such as inverters and storage batteries are hidden under the concrete seats. They are not easily accessible or detectable by the users. The solar panels were also designed to provide shade so they could perform two functions at the same time. Two types of benches were designed. One has a stone seating place shown in Figure 5a and the other has a wooden seating place shown in Figure 5b. Both of them are equipped with charging outlets. The wooden benches also have wind belts on the back, under the solar panels. The total height of the seating unit is $2.1 \mathrm{~m}$ and the seats are placed at a height of $45 \mathrm{cms}$. The dimension of the PV panels placed on top of the benches is $1.65 \mathrm{~m} \mathrm{x} 0.99 \mathrm{~m}$. The three benches which are located in the south, southeast and southwest directions, form a semicircle seating unit in the park. In other words, they have an orientation of +30 degree,-30 degree and 0-degree azimuth angle. As seen in Figure 7, thirty-six seating units are located in the park.

On the south direction, six charge stations shown in Figure 6a were designed. The total height of these stations is designed as $2.1 \mathrm{~m}$ with a concrete base $0.85 \mathrm{~m}$ high. As landmark equipment, two renewable energy trees shown in Figure 6b were designed and they were placed in front of the two entrance area of the Park. In addition, boards providing information on the area were designed. One side of these boards is digital and the other is the classic board to put up paper ads.

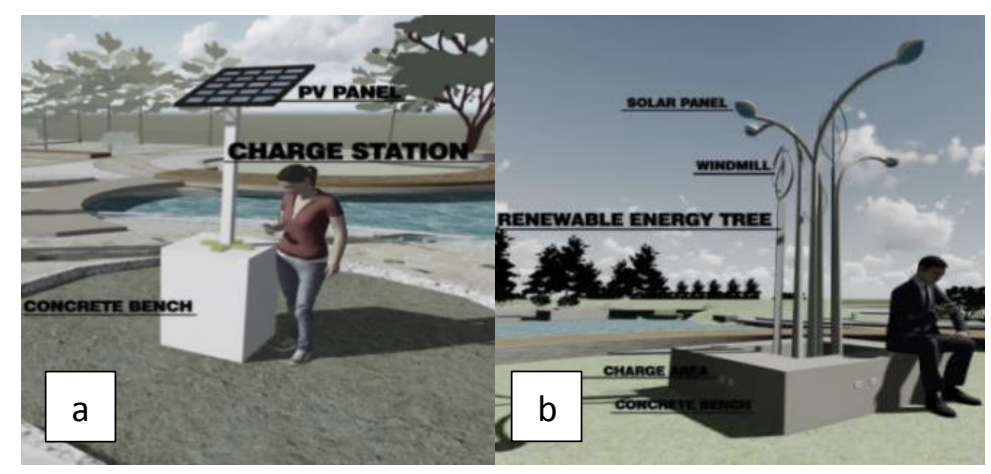

Figure 6. a) Designed charge station b) Designed renewable energy tree 


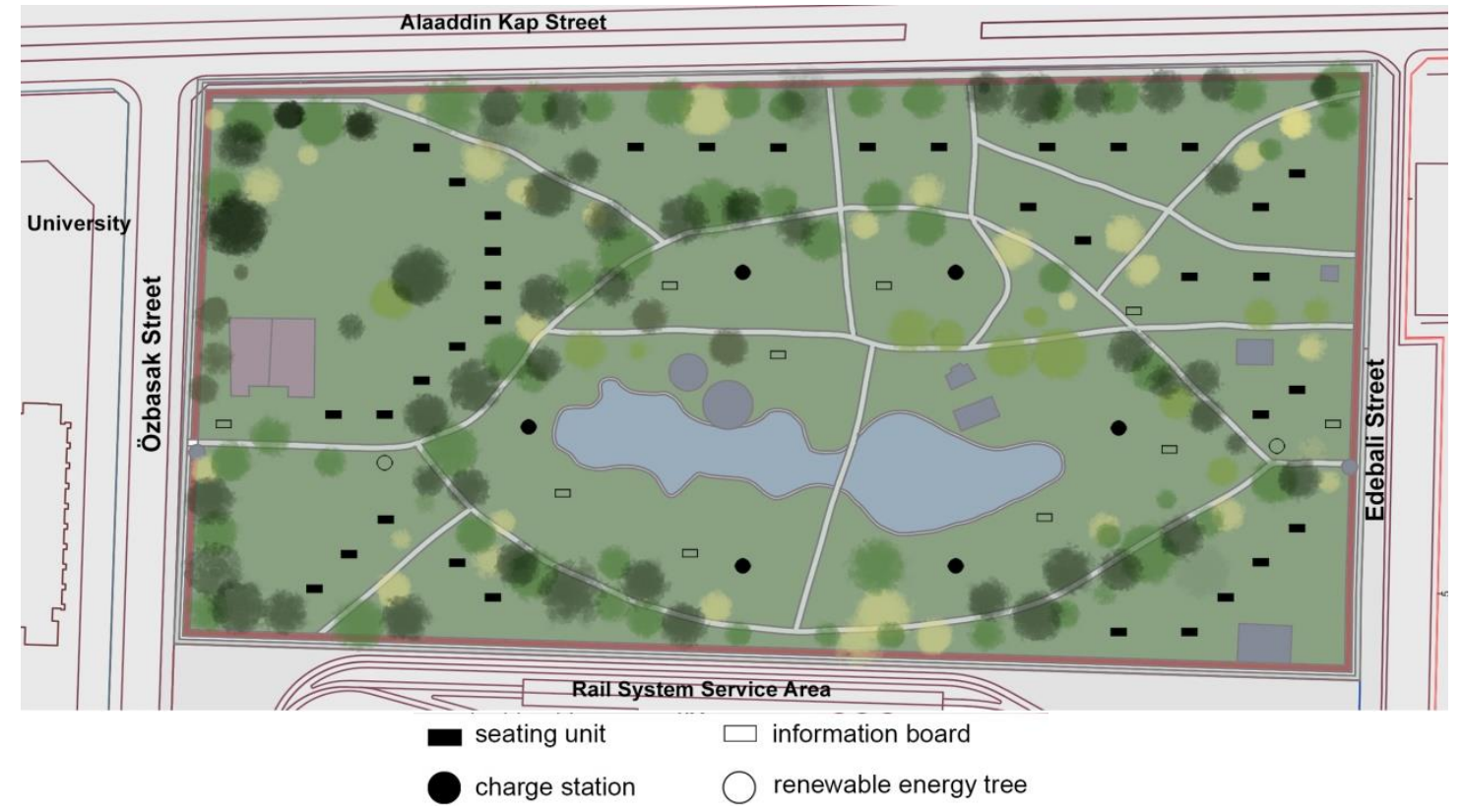

Figure 7. Layout plan of designed urban furniture for the case study area (1/2500 scaled)

The layout plan of the new designed urban furniture according to grid arrangement can be seen in Figure 7. The total installations are assumed to have $50 \mathrm{MWh} /$ an electricity production capacity. This energy can be used to meet the lighting and electrical needs of the area and thus the park can be a free energy area for all users.

\section{CONCLUSION}

The quality of our environment is a result of our chosen living style. It has already been proved that renewable energy is the way forward since it contributes to the sustainability of our environment. Recreational areas are important public places serving a large number of users. Since these areas are accepted as green and clean places, it is necessary to keep them away from all kinds of contamination. Therefore, renewable energy technology applications in these areas will generate motivation and keep parks free from all pollutants. Besides, the technology can be spread through the adaptation in public places. As a consequence, the use and dissemination of renewable energy technologies in public spaces will promote the use of these technologies everywhere.

Allocating a special and separate place for renewable energy systems is not favourable for their integration. The ideal approach is to combine renewable energy technology with urban furniture. After the energy potential research on the field is conducted and the appropriate resources are selected, it is necessary to use the technology in line with the design concept of the park. Security, durability, and resiliency of the system should be checked, taking into consideration the furniture design.

In the park areas, these new technologies can be combined with some natural materials so their integration into the area can be achieved in a subtle way. Designs in line with today's needs should also meet the changing needs of people who spend their leisure time in recreational areas. The charging units to answer the needs of people, who spend time with their mobile phones or other electronic devices, can be easily integrated into these designs. Similarly, these designs can also be equipped with billboards in order to provide information for citizens. Companies manufacturing urban furniture should change their direction and adapt themselves in line with this new concept. More importantly, local authorities should set these conditions in their tender documents, so all recreational open spaces can be transformed into free energy areas. 


\section{CONFLICTS OF INTEREST}

No conflict of interest was declared by the authors.

\section{REFERENCES}

[1] Oldenburg, R., The Great Good Place, Paragon, New York, (1989).

[2] Francis, J., Giles-Corti, B., Wood, L., Knuiman, M., "Creating sense of community: The role of public space," Journal of Environmental Psychology, 4(32): 401-409, (2012).

[3] Torkildsen, G., Leisure and Recreation Management, Routledge, London, NY,(1999).

[4] Roberts, K., "Sociology of leisure," Sociology of leisure, Key Articles in British Sociology: BSA 60th anniversary special collection: 1-13, (2011).

[5] Jennings, V., Larson, L., Yun, J., "Advancing Sustainability through Urban Green Space: Cultural Ecosystem Services, Equity, and Social Determinants of Health," International Journal of Environmental Research and Public Health, 13(2): 196, (2016).

[6] Brown, R. I., Brown, I., "The application of quality of life," Journal of Intellectual Disability Research, 10(49):718-727, (2005).

[7] REN21 Secretariat, "Ren 21, Renewables 2017 Global Status Report," Renewable energy policy network for the 21st century, Paris, (2017).

[8] Bill, M., Gail Greet, H., Site Furnishings: A Complete Guide to the Planning, Selection and Use of Landscape Furniture and Amenities, John Wiley \& Sons, Hoboken,NJ,(2010).

[9] Volkan Aksu, Ö., "Kent mobilyaları tasarımında özgün yaklaşımlar,” İnönü Ün. Sanat ve Tasarım, 2(6):373-386, (2012).

[10] Ghorab, P., Yücel Caymaz, G. F., "Evaluation of street furniture according to basic design principles," International Journal of Electronics, Mechanical and Mechatronics Engineering (IJEMME), 3(4):757$772,(2014)$.

[11] Güremen, L., "A research about urban furniture in the aspect of urban identity and aesthetics of Amasya province," E-journal of New World Social Sci., 6: 254-291, (2011).

[12] Enis Faik, A., Evci, F., Approach to Architectural Design: Building Information Studies, Tasarım Yayın Grubu, İstanbul, (1992).

[13] Şatır, S., Korkmaz, E., "Urban open spaces with examples \& the classification," A|Z ITU Journal of the Faculty of Architecture, 1/2(2):130-141, (2005).

[14] Günal Ertaş, D., Bayazit, N., "Effect of Structure and Material Properties on Industrial Product Design," in 2nd National Building Material Congress, İstanbul, (2004).

[15] Dascalau, D. M., "Landscape effects of urban furniture textures," Bulletin UASVM Horticulture, 1(68): 324-331, (2011).

[16] Altınçekiç, H., "Peyzaj mimarlığında renk ve önemi," İstanbul Üniversitesi Orman Fakültesi Dergisi, B-50(2): 79-83, (2000). 
[17] Ashby, M., Johnson, K., Materials and Design, Elsevier Butterworth Heinemann, London, (2004).

[18] Smardzewski, J., Furniture Design, Springer, Switzerland, (2015).

[19] Lack, C. A., "Urban Wind Turbines", Master Thesis, Talinn University of Technology, Tallinn, 5397 (2012).

[20] Najini, H., Muthukumaraswamy, S. A., "Investigation on the selection of piezoelectric materials for the design of an energy harvester system to generate energy from traffic," International Journal of Engineering and Applied Science, 2(3): 43-49, (2016).

[21] Kanhe, S., Kurhade, S.,Khaparkar, A., "Electricity Generation Using Wind Belt Technology," International Research Journal of Engineering and Technology, 4(01): 1416-1419, (2017).

[22] Astudillo-Baza, Y., Zepeda, M. A. L., Torres Sabino, M., "Getting Electric Power for Piezoelectricity," The International Journal of Engineering And Science, 5(12):38-43, (2016).

[23] EIE, "The Atlas of Turkey wind energy potential,” Ankara, (2011). 